UDC 581.1

\title{
INTRODUCTION OF NEOTTIA NIDUS-AVIS (L.) RICH INTO CULTURE IN VITRO
}

\section{E. A. Sheyko, L. I. Musatenko}

M. G. Kholodny Institute Botany NAS of Ukraine, 2, Tereshenkivska St., Kyiv 01601, Ukraine e-mail: phytohormonology@ukr.net

Callus cultures from ovary and ovule of Neottia nidus-avis (L.) Rich. were obtained. Dependence of callus genesis on growth regulators composition of nutrient medium it was shown. Cytomorphological analysis of callus cultures demonstrat their high morphogenetic potential.

Key words: Orchidaceae Juss., callus culture, ovary, ovule.

\section{INTRODUCTION}

The Orchidaceae Juss family - orchidaceous is one of the largest families of the angiosperms. A specific biological feature of plants representing this family is their low, in comparison with other plant species, competitiveness. Under the influence of adverse natural conditions orchids have acquired adaptation-metamorphous modifications (modified roots, leaves and shoots), specific combination of development rhythms and dormancy periods, specificity of metabolism as well as changes in pollination patterns that have resulted in their structure diversity $[1,5,7]$. Orchids of Ukraine are perennial ground herbs which include a specific group of the saprotrophic species among which there is Neottia nidus-avis (L) Rich. These species exist owing to the symbiosis with fungi [8]. The orchid family includes the greatest number of rare and extinct species [11].

Thus, such bio-ecological characteristics as a low competitiveness and mycosymbiotropism as well as specific pollination, inbreeding processes of small in number populations, decorative and attractive features make orchids the most impressive group of plants. Today the problem of wild-growing orchids protection in the temperate zone is very important and that is why the preservation of rare orchid species gene pool requires their more global and detail studies.

One of possible ways of the orchid preservation is their propagation in vitro, and wide introduction in practical agricultural production as highly decorative plants and at the same time their return into natural environment [9]. Clonal techniques of tropic orchid reproduction in vitro were developed in the sixties of the twentieth century and today they are still widely used. They are very effective and their application provides possibility for preserve species for many years. Experiences in seed and macro-clonal 
reproduction of wild-growing orchids of the temperate zone have already been gained, while micro-clonal reproduction remains less studied. The most interesting results have been obtained on reproduction of the genus Cypripedium L. [2, 3]. A promising direction in this field is the development of biological approaches in cultivating in vitro both vegetative and generative structures such as anther, ovary and seed germs because they have a high morphogenetic potential and are characterized by some autonomy from the mother plant [10]. This process is essentially based on the transition of the development program of morphogenetically competent cells in generative structures from the regular gametophyte way to sporophyte one that is to the production of a regenerative plant.

The objective of this work was to elaborate an accelerated method of $N$. nidus-avis reproduction using a culture in vitro, optimization of the explants cultivation conditions, obtaining a callus culture and investigation of its morphogenetic potential.

\section{MATERIALS AND METHODS}

A representative of the orchid family (Orchidaceae) Neottia nidus-avis (L) Rich was used. This is a perennial herbal, saprophytic, rooted plant, $20-45 \mathrm{~cm}$. high, with a lightbrown stem and plate like leaves. It has the big yellow-brown flowers making a long inflorescence and giving off a smell of honey. It blossoms in June, bears on August September, reproduces by seeds, sometimes by stump planting (using roots). Seeds germinate in soil involving a fungus. An overground sprout develops on 9-10 th year and two months after flowering it fades. Sometimes inflorescence is unable to push through the ground and flowers have to conceive underground (they are characterized by cleistogamy). Sometimes seeds sprout just in a box. It is widely spread in the forest areas of Europe and Eastern Siberia, Asia Minor and the Caucasus. In Ukraine N. nidus-avis can be found in Carpathian Mountains, in the forest and forest-steep zones, in the north of the steep zone and in mountains of Crimea. It grows in deciduous forests on rich soils. It was once something common to find $N$. nidus-avis in the Ukrainian forests but now, unfortunately, its quantity is gradually decreasing. It results basically from the fact that the natural habitats of this species are damaged and forest recreation produce negative effects $[6,8]$.

As explants we used ovaries, seed germs and stem segments. For cultivation applied nutrient media Murashige and Skoog, Nitch and Nitch, Reinert and Mohre and modified Knudson medium [4]. Our attempt to cultivate N. nidus-avis stem segments gave no positive results. Seed germs and ovaries were collected on $25-30^{\text {th }}$ day after the flowering start. Explants were planted on a nutrient medium following their sterilization. Seed germs and ovaries were cultivated in flasks and test-tubes on agarized nutrient media mixed with 6-BAP (6-Benzylaminopurine), 2,4-D (2,4-Dichlorophenoxyacetic acid), IBA (Indole-3-butyric acid). Cultivation conditions: temperature $-23-25^{\circ} \mathrm{C}$, illumination $-2-3$ thousands of lux with 10 hour photoperiod, air relative humidity $-60 \%$. Cytological studies of callus were done on temporary preparations stained with acetocarmine using the microscope $\mathrm{MBI}-3(\times 8, \times 20, \times 90)$.

\section{RESULTS AND DISCUSSION}

Plant cultivation in vitro with the purpose of obtaining the callus and regenerative plants is impossible without obtaining an aseptic culture. In our studies we tested two methods of sterilization. At the initial stages of the experiment it was planned to choose

ISSN 1996-4536 • Біологічні Студії / Studia Biologica • 2011 • Том 5/№1 • С. 113-118 
sterilant and mode of sterilization that would enable to get a maximum quantity of a sterile material with a minimum loss of explants. In order to meet the requirements of the sterility, the explants were introduced into an isolated culture in a laminar box. Material surface sterilization was carried out in $70 \% \mathrm{C}_{2} \mathrm{H}_{5} \mathrm{OH}-\left(4 \mathrm{~min}\right.$.), $70 \% \mathrm{C}_{2} \mathrm{H}_{5} \mathrm{OH}(2 \mathrm{~min}$.) with $15 \% \mathrm{H}_{2} \mathrm{O}_{2}$ (3 min.), and $15 \% \mathrm{H}_{2} \mathrm{O}_{2}(4 \mathrm{~min}$.) (Table).

\section{Effects of various sterilants on obtaining an aseptic culture and viability of $\boldsymbol{N}$. nidus-avis explants}

Вплив різних стерилентів на отримання асептичної культури та життєздатність експлантів $\mathbf{N}$. nidus-avis

\begin{tabular}{c|c|c|c}
\hline \multirow{2}{*}{ Explant } & $\begin{array}{c}\text { Sterilants and mode of } \\
\text { sterilization }\end{array}$ & $\begin{array}{c}\text { Quantity of aseptic } \\
\text { explants, \% }\end{array}$ & $\begin{array}{c}\text { Quantity of viable } \\
\text { explants, \% }\end{array}$ \\
\hline \multirow{5}{*}{ Seed germs } & $70 \% \mathrm{C}_{2} \mathrm{H}_{5} \mathrm{OH} 4$ min. & 95.3 & 3.4 \\
\cline { 2 - 4 } & $\begin{array}{c}70 \% \mathrm{C}_{2} \mathrm{H}_{5} \mathrm{OH} 2 \text { min., } \\
15 \% \mathrm{H}_{2} \mathrm{O}_{2} 3 \mathrm{~min} .\end{array}$ & 60.9 & 58.8 \\
\cline { 2 - 4 } & $15 \% \mathrm{H}_{2} \mathrm{O}_{2} 4 \mathrm{~min}$. & 9.0 & 8.6 \\
\hline \multirow{5}{*}{ Ovaries } & $70 \% \mathrm{C}_{2} \mathrm{H}_{5} \mathrm{OH} 4$ min. & 89.2 & 5.9 \\
\cline { 2 - 4 } & $\begin{array}{l}70 \% \mathrm{C}_{2} \mathrm{H}_{5} \mathrm{OH} 2 \mathrm{~min} . \\
15 \% \mathrm{H}_{2} \mathrm{O}_{2} 3 \mathrm{~min} .\end{array}$ & 59.7 & 55.1 \\
\cline { 2 - 4 } & $15 \% \mathrm{H}_{2} \mathrm{O}_{2} 4 \mathrm{~min}$. & 7.6 & 6.4 \\
\hline
\end{tabular}

The highest sterility during the preparation of aseptic explants of N. nidus-avis generative organs was achieved when $70 \%$ ethanol was used. The amount of aseptic explants obtained by this method of sterilization was for seed germs $95.3 \%$, for ovaries $89.2 \%$, whereas the maximum percentage of viable explants for seed germs amounted to $3.4 \%$ and for ovaries $-5.9 \%$. When there was applied $15 \% \mathrm{H}_{2} \mathrm{O}_{2}$ the quantity of aseptic and viable explants was very low and did not exceed $9 \%$, that did not met requirements of the experiment.

A double sterilization with $70 \% \mathrm{C}_{2} \mathrm{H}_{5} \mathrm{OH}$ (2 min.) along with $15 \% \mathrm{H}_{2} \mathrm{O}_{2}$ (3 min.) was an optimal one. This method of sterilization was further on applied since the index of explant viability was high and reached $55.1 \%$ for ovaries and 58.8 for seed germs, respectively.

A significant aspect in the elaboration of the culture in vitro techniques is the selection of a nutrient medium with an optimal concentration of growth substances for the callus induction. In our experiments we applied four nutrient media Murashige and Skoog, Nitch and Nitch, Reinert and Mohre and modified Knudson medium. The medium composition was modified to induce the genesis of callus and to obtain the initial callus tissue as quick as possible. As basic dedifferentiating factors there were synthetic analogues of natural phytohormones: BAP, 2,4-D, IBA. Concentrations of these growth substances varied from $0.5 \mathrm{mg} / \mathrm{l}$ to $3.0 \mathrm{mg} / \mathrm{l}$. The obtained data enabled us to conclude that the media Murashige and Skoog, Nitch and Nitch media with various growth substance concentrations are the most appropriate for cultivating tissues of $\mathrm{N}$. nidus-avis generative organs. 
When cultivated on other nutrient media, generative organs showed negative results in all variants studied. The maximum frequency of the callus formation for ovaries $(19.2 \pm 1.5)$ was observed when the Murashige and Skoog medium combined with $2.5 \mathrm{mg} / \mathrm{l}$ of 6 -BAP, $3.0 \mathrm{mg} / \mathrm{l}$ of IBA was used. For seed germs $(21,5 \pm 0,8)$ the most effective was Nitch and Nitch medium combined with $1.5 \mathrm{mg} / \mathrm{l}$ 2,4-D, $2 \mathrm{mg} / \mathrm{l}$ of 6-BAP (Fig.).

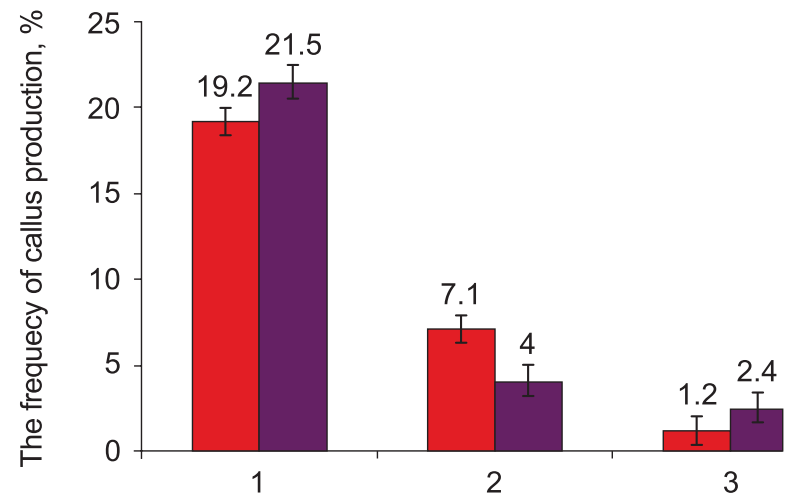

Effects of phytohormones on frequency of callus formation in culture of ovaries $\square$ and seed germs N. nidus-avis in vitro: $1-2.5 \mathrm{mg} / \mathrm{l}$ of 6 -BAP; $3.0 \mathrm{mg} / \mathrm{l}$ of IBA; $2-0.5 \mathrm{mg} / \mathrm{l}$ of 6-BAP; 3 - hormone-free nutrient media. For cultivation of ovaries Murashige and Skoog nutrient media were used, and for seed germs, Nitch and Nitch nutrient media were used

Вплив фрітогормонів на частоту калюсоутворення в культурі зав'язей $\square$ і насінних зачатків Neottia nidus-avis in vitro: 1 - 2,5 мг/л 6-БАП; 3,0 мг/ л ІМК ; 2 - 0,5 мг/л 6-БАП; 3 - безгормональні поживні середовища. Для культивування зав'язей використовували поживне середовище Мурасіге-Скуга, для насінних зачатків - Ніча та Ніч

The results of studies aimed to choose the optimal cultivation conditions made it possible to obtain a callus culture from $N$. nidus-avis ovaries and seed germs. No differences in the cell structure of the callus obtained from the both types of explants were observed. The cytological analysis of these cultures revealed a number of specific features. They were: 1) a significant structural heterogeneity of cells, the presence of various types of formations different on their morphology; 2) dependence of the morphological characteristics in some formations on their morphological potency. In the callus there were found groups of small meristematic cells with great nuclei, which indicates the start of dedifferentiating processes in the callus tissue.

In the callus there were found groups of small meristematic cells with great nuclei that indicates the start of dedifferentiating processes in the callus tissue. In such groups of cells the morphogenesis is known to occur in two ways [4]. Meristem cells division may cause the formation of lignified conducting elements of vessels and tracheids. Their formation is similar to the xylem genesis in intact plants and consists of the stages: cell growth, vacuolization, formation of secondary cell wall in conditions of in vitro.

Another way of the morphogenesis is a spontaneous embryogenesis. But in this case the callus cell that is involved in the embryogenesis, is relatively isolated from surrounding cells by a dense cell wall, increases in size and intensively changes its color. The isolated cell is characterized by strictly directed divisions. As a result of the formation of oriented cellular septa develops a four-cell structure (tetrad) all cells of which are arranged in line. The subsequent embryo development involves both the apical and basal cells and there appears a multi-cellular embryoid.

ISSN 1996-4536 • Біологічні Студії / Studia Biologica • 2011 • Том 5/№1 • С. 113-118 
Regardless of a great number of disturbances during embryogenesis, the development of some embryoids is similar to that of zygotic embryo and is characterized by the same stages: embryonic, globular and torpedo-like and like this somatic embryoids that were obtained in culture of seed germs and ovaries, may be used as initial material for the plants reproduction.

\section{CONCLUSIONS}

1. The optimal conditions of obtaining aseptic explants of $N$. nidus-avis for the introduction into culture in vitro namely, the double sterilization with $70 \% \mathrm{C}_{2} \mathrm{H}_{5} \mathrm{OH}$ along with $15 \% \mathrm{H}_{2} \mathrm{O}_{2}$ were revealed.

2. The nutrient media (with biologically active substances) for cultivating in vitro ovaries and seed germs of saprotrophic orchid were selected. The maximum frequency of the callus formation for ovaries was observed when there was used the Murashige and Skoog medium combined with $2,5 \mathrm{mg} / \mathrm{l}$ of $6-\mathrm{BAP}$, $3.0 \mathrm{mg} / \mathrm{l}$ of IBA. For seed germs $(21.5 \pm 0.8)$ the most effective was Nitch and Nitch medium combined with $1.5 \mathrm{mg} / \mathrm{l} 2,4-\mathrm{D}, 2 \mathrm{mg} / \mathrm{l}$ of $6-B A P$.

3. For the first time there were obtained callus cultures from $N$. nidus-avis ovaries and seed germs.

1. Kolomiyceva G.L. Orchids and its pollinators. The Science and life, 2002; 8: 141-145.

2. Kulikov P.V., Philipov E.G., Mamaev S.A. Seminal and microclonal germination of orchids of Ural on Botanic garden NAS of Russia. In the book: The analysis and prognostication of results of introduction ornamental and medicina plants of world flora on Botanical Gardens. Materials of the II international conference. Minsk, 1996. Minsk, 1996: P. 34-35.

3. Kulikov P.V. Seminal and microclonal germination of species of genus Cymbidium L. on culture in vitro. Bul. of I.S. Kosenko Botanical. Garden Kuban nation agruniversity, 1998; 7 : 85-87.

4. Kushnir G.P., Sarnacka V.V. Microclonal germination of plant. K.: Nauk. dumka, 2005. 272 p.

5. Popkova L.L. Orchids of Crimea: biology, ecology, conservation. Periodicals of the Nikit. Botanical. Garden, 2001; 120: 41-53.

6. Sobko V.G. Orchids of Ukraine. K.: Nauk. dumka, 1989. 192 p.

7. Sobko V.G., Gaponenko M.B. The vegetative reproduction of relict and precinctive orchids species of Ukrainian flora. In the book: The protection and cultivation of orchids. Materials of the international scientific conference. Kyiv, September 1999. Kyiv, 1999: 76-78.

8. Tatarenko I.V. Biomorphological peculiarity of Neottia nidus-avis (Orchidaceae ). Bot. Journ, 2002; 87(11): 60-67.

9. Teplitskaya L.M., Popkova L.L., Bugara A.M., Kotov S.P. The conservation of vegetable gene pool of orchids of Crimeaby method cultivation in vitro. The ecosystem of Crimea their optimization and protection, 2002; 12: 39-43.

10. Terechin E.S. The embryology flowering plants. The terminology and conceptions. Vol 3. The system of reproduction. St. Petersburg: The World and Family, 2000. 651c.

11. Cherevchenko T.M., Buyun L.I., Kovalskaya L.A., Vahrushkin V.S. Orchids. K.: Prosvita, 2001. $223 p$. 


\section{ВВЕДЕННЯ В КУЛЬТУРУ IN VITRO NEOTTIA NIDUS-AVIS (L.) RICH}

О. А. Шейко, Л. І. Мусатенко

Інститут ботаніки ім. М. Г. Холодного НАН України вул. Терещенківська, 2, Київ 01601, Україна

e-mail: phytohormonology@ukr.net

Отримано калюсні культури зав'язей і насінних зачатків Neottia nidus-avis (L.) Rich. Показана залежність процесу калюсогенезу від фрітогормонального складу поживного середовища. Цитоморфологічний аналіз калюсних культур показав їхній високий морфогенетичний потенціал.

Ключові слова: Orchidaceae Juss., калюсна культура, насінні зачатки, зав'язі.

\section{ВВЕДЕНИЕ В КУЛЬТУРУ IN VITRO NEOTTIA NIDUS-AVIS (L.) RICH}

\section{Е. А. Шейко, Л. И. Мусатенко}

Институт ботаники им. М. Г. Холодного НАН Украины ул. Терещенковская, 2, Киев 01601, Украина e-mail: phytohormonology@ukr.net

Получены каллусные культуры из завязей и семенных зачатков Neottia nidusavis (L.) Rich. Показана зависимость процесса каллусогенеза от фритогормонального состава питательной среды. Цитоморфологический анализ каллусных культур показал их высокий морфогенетический потенциал.

Ключевые слова: Orchidaceae Juss., каллусная культура, семенные зачатки, завязи. 